\title{
KETERKAITAN KESEHATAN SPIRITUAL (SPIRITUAL WELL- BEING) DAN ORIENTASI KEPUTUSAN ETIS (ETHICAL ORIENTATION OF DECISION MAKING) (Studi Empiris terhadap Para Pembuat Keputusan di Indonesia Tahun 2016)
}

\author{
I Cenik Ardana, Elizabeth Sugiarto D \& Yuniarwati \\ Fakultas Ekonomi Universitas Tarumanagara Jakarta \\ Email: icenik_ardana@yahoo.com
}

\begin{abstract}
Specifically, the purpose of this study is: (1) to test the validity and reliability of the measurement model of Fisher's spiritual well-being (SWB) construct (2010); (2) to test the validity and reliability of the measurement model of Forsyth's ethical orientation of decision-making (EDM) construct (1980), and (3) to examine the correlation of Fisher's SWB variables with Forsyth's EDM variables (1980). Testing instruments or measurement models uses confirmatory factor analysis and Cronbach Alpha's reliability and testing correlation uses Perlson's correlation. The data is processed with SPSS version 22. The results of this study showed that: (1) the measurment model of Fisher's SWB construct is valid and reliable; (2) the measurment model of Forsyth's EDM construct is also valid and reliable. It is also concluded that there is a positive and significant correlation between ideal spiritual well-being (ISWB) construct, either in whole (ISWB) and each dimension (ICSWB, IPSWB, ITSWB, IESWB) with ideal ethical orientation of decision-making (IEDM). There is also a positive and significant relationship between lived spiritual well-being (LSWB) construct as a whole with relative ethical orientation of decision-making (REDM). In testing the correlation of each dimension of LSWB construct (LCSWB, LPSWB, LTSWB, LESWB) with REDM construct, despite all the dimensions of LSWB shows positive correlations with REDM, but the level of significance of the association varies.
\end{abstract}

Keywords: spiritual well-being, ethical orientation of decision making

\begin{abstract}
Abstrak: Secara spesifik, tujuan penelitian ini adalah untuk: (1) menguji kelayakan model pengukuran atau instrumen penelitian konstrak kesehatan spiritual model Fisher (2010), (2) menguji kelayakan model pengukuran atau instrumen penelitian konstrak orientasi etikal pembuatan keputusan model Forsyth (1980), dan (3) menguji keterkaitan variabel kesehatan spiritual Fisher dengan variabel orientasi etikal keputusan Forsyth (Forsyth, 1992, dalam Chan \& Othman, 2011). Pengujian model pengukuran atau instrumen penelitian menggunakan analisis faktor konfirmatori dan Cronbach Alpha's reliability, dan pengujian korelasi menggunakan Perlson' correlation. Data diolah dengan SPSS versi 22. Hasil penelitian ini menunjukkan bahwa; (1) model pengukuran konstrak kesehatan spiritual yang dikembangkan oleh Fisher adalah valid dan dapat diandalkan; (2) model pengukuran konstrak orientasi etikal keputusan Forsyth juga valid dan dapat diandalkan. Disimpulkan pula bahwa terdapat keterkaitan secara positif dan signifikan antara konstrak kesehatan spiritual ideal, baik secara keseluruhan (ISWB) maupun masing-masing dimensi (ICSWB, IPSWB, ITSWB, IESWB) dengan konstrak orientasi etikal ideal pembuatan keputusan (IEDM). Juga terdapat keterkaitan secara positif dan signifikan antara konstrak
\end{abstract}


pengalaman kesehatan spiritual secara keseluruhan (LSWB) dengan konstrak orientasi etikal relatif pembuatan keputusan (REDM). Dalam pengujian keterkaitan masing-masing dimensi LSWB (LCSWB, LPSWB, LTSWB, LESWB) dengan konstrak REDM, meskipun seluruh dimensi LSWB menunjukkan keterkaitan secara positif dengan REDM, namun tingkat signifikansi keterkaitannya bervariasi.

Kata Kunci: kesehatan spiritual, orientasi keputusan etis dalam pembuatan keputusan

\section{PENDAHULUAN}

Dalam beberapa tahun terakhir ini, pelanggaran terhadap berbagai peraturan dan kode etik bisnis telah sangat meluas terjadi di berbagai negara di dunia dengan intensitas dan kompleksitas yang semakin meningkat. Beberapa kasus dari banyak kasus keputusan yang melanggar etika dan hukum yang menonjol (http://en.wikipedia.org/wiki/Accounting scandals.com,2016) antara lain: kasus Enron, WorldCom, Waste Management, Lehman Brothers (Amerika Serikat), Associated Electrical Industries, Pergamon Press, Bank of Credit and Commerce International (Inggris), HIH, James Hardie, dan Opes Prime (Australia), Lernout \& Hauspie (Belgia), Parmalat (Italia), Nortel (Kanada), Olympus Corporation (Jepang), dan masih banyak lagi kasus-kasus lainnya. Di Indonesia, kasus yang menonjol, antara lain: kasus BLBI, Bank Century, Lumpur Lapindo, pembakaran hutan oleh korporasi dan sebagainya.

Dari fakta di atas terlihat bahwa kode etik, peraturan dan regulasi dari lembaga/otoritas eksternal saja belum cukup efektif untuk meredam berbagai tindakan dan keputusan bisnis tidak etis dari para pemimpin korporasi. Perlu diinvestigasi faktor-faktor lain, khususnya faktor internal di dalam diri para pengambil keputusan yang ikut menentukan orientasi keetisan dari suatu proses keputusan, yang salah satu aspeknya berkaitan dengan "spritualitas". Ardana, Dermawan, dan Susanti (2016) telah menganalogikan keterkaitan faktor eksternal (regulasi dan peraturan) dengan faktor internal (kesadaran diri) sebagai "the man behind the gun". Keefektivan regulasi dan peraturan (the gun) untuk membangun sikap dan perilaku etis, memerlukan pula dukungan tak terpisahkan dari kesadaran diri (the man) para pemangkukepentingan terkait dalam menjalankan bisnis. Salah satu unsur kesadaran diri adalah kesehatan spiritual (spiritual well-being).

Sistem nilai dan kepercayaan individu dan masyarakat terus mengalami perubahan. Jika individu-individu dan masyarakat menganut sistem nilai dan kepercayaan yang negatif, akan berimbas negatif pula pada perusahaan dan korporasi, yang pada akhirnya meluas ke lingkungan sosial dan alam (Agbim, Ayatse \& Oriarewo, 2013). Para pakar etika bisnis pada umumnya bersepakat bahwa dalam hal pelaku bisnis menghadapi situasi keputusan bisnis yang sarat dengan konten etika, pelaku bisnis tersebut akan menggunakan tuntunan etika yang bersumber dari filosofi moralnya. Filosofi moral merujuk pada prinsip-prinsip atau aturan-aturan yang ia gunakan untuk memutuskan apakah suatu keputusan atau tindakan yang diambil adalah benar atau salah (Fernando \& Chowdhury, 2010). Dalam salah satu model etika bisnis, filosofi moral pribadi seseorang menjadi salah satu faktor penting yang mempengaruhi proses keputusan bisnis (Ferrell and Gresham, 1985; Hunt and Vitell, 1986, dalam Chan and Othman, 2011). Forsyth (1992), dalam Chan \& Othman (2011) mengemukakan bahwa ada 2 (dua) perspektif populer tentang filosofi moral pribadi, yaitu apa yang disebut sebagai etika idealisme dan etika relativisme. Etika idealisme didefinisikan sebagai derajat keyakinan seseorang yang 
menganggap bahwa dengan tindakan benar (the right action), konsekuensi yang diinginkan akan selalu dapat diperoleh. Di lain pihak, etika relativisme dipahami sebagai seberapa besar keyakinan seseorang untuk menolak aturan moral universal saat melakukan penilaian etis. Kedua konstruk ini - etika idealisme dan etika relativisme -, dianggap sebagai variabel yang independen dan orang-orang bisa tinggi atau rendah pada kedua dimensi ini.

Kesehatan spiritual (spiritual well-being/SWB), merupakan hasil dari pengalaman spiritual - berkaitan dengan kesehatan totalitas seluruh sumberdaya internal setiap manusia, menjadi tumpuan semua nilai dan filosofi kehidupan untuk menuntun perilaku dan memberi makna kehidupan yang mempengaruhi perilaku sosial dan individual (Fernando \& Chowdhury, 2010). Sebagai konstruk baru dalam ranah ilmu, SWB masih diberi istilah dan makna yang luas dan beragam (Aravamudhan, 2007). Dalam penelitian ini, pengertian dan model pengukuran SWB mengacu pada apa yang diungkapkan oleh Fisher (2010). Para peneliti dengan latar belakang keilmuan yang beragam belakangan ini mulai tertarik untuk mengkaji aspek kecerdasan atau kesehatan spiritual, namun penelitian yang mengaitkan kesehatan spiritual dengan orientasi etis keputusan belum banyak dilakukan. Fernando dan Chowdhury, (2010) telah meneliti keterkaitan kesehatan spiritual (SWB) dengan orientasi etis pengambilan keputusan (ethical orientation of decision making ( EDM) para eksekutif perusahaan publik di Australia dengan menggunakan model Fisher (2010) untuk mengukur $S W B$ dan model Forsyth (1980) untuk mengukur EDM. Hasilnya terbukti bahwa $S W B$ mempunyai keterkaitan erat dengan $E D M$, khususnya orientasi etis keputusan yang bersifat ideal.

Penelitian ini mencoba menginvestigasi unsur kesehatan spiritual (SWB) sebagai salah satu faktor internal (dari dalam diri) yang mungkin terkait dengan keetisan suatu proses keputusan. Perumusan pokok masalahnya adalah: (1) apakah ada keterkaitan Kesehatan Spiritual Ideal (Ideal Spiritual Well-Being/ISWB) baik secara keseluruhan maupun masing-masing domain: communal, personal, transcendental, dan environmental dengan Orientasi Etikal Ideal Pembuatan Keputusan (Ideal Ethical Orientation of Decision Making/IEDM), (2) apakah ada keterkaitan Pengalaman Kesehatan Spiritual (Lived Spiritual Well-Being/LSWB) baik secara keseluruhan maupun masing-masing domain: communal, personal, transcendental, environmental dengan Orientasi Etikal Relatif Pembuatan Keputusan (Relative Ethical Orientation of Decision Making/REDM).

Kesehatan spiritual (spiritual well-being). Pengertian "sehat" menurut World Health Organisation/WHO adalah: "Health is a state of complete physical, mental and social well-being and not merely the absence of disease or infirmity" (WHO, http://www.who.int/). Belakangan ini, WHO (2013) menambahkan dimensi ke-empat tentang kesehatan, yaitu dengan menambahkan kesehatan spiritual. Dengan demikian WHO (2013) memberikan definisi sehat dalam arti luas, tidak hanya sekedar tidak adanya penyakit atau pengobatan, namun menyangkut suatu keadaan sejahtera (well-being) yang lengkap meliputi empat dimensi: fisik, mental, sosial, dan spiritual.

Sebagai langkah awal untuk memahami kesehatan spiritual, perlu terlebih dahulu memahami: (1) perbedaan spiritualitas dengan agama, dan (2) batasan atau definisi tentang kesehatan spiritual. Tackney and Harris (2015), dalam Chappell (2016) memberikan batasan yang jelas tentang agama (religion) dan spiritualitas. Selanjutnya dikatakan bahwa agama (religion) sebagai: "the institutional/ historical manifestation of the capacity of the human consciousness to apprehend ultimate meaning and ultimate value symbolically", sedangkan spiritualitas (spirituality) adalah: "the capacity of the human consciousness to 
apprehend ultimate meaning and ultimate value symbolically". Agama lebih menekankan pada aspek sejarah dan kelembagaan sekitar nilai dan makna akhir, sedangkan spiritualitas menekankan pada aspek derajat kesadaran yang berkaitan dengan nilai dan makna akhir suatu kehidupan. Kebanyakan ilmuwan sepakat dengan pembedaan ini.

Dalam memberikan batasan atau definisi tentang spiritualitas atau kesehatan spiritual tidaklah mudah. Sebagaimana dikatakan oleh McGhee (2015), bahwa kesehatan spiritual merupakan konstruk yang ambigu, sangat beragam dan sulit diberikan definisi yang tepat. Untuk memberikan gambaran tentang hal ini, berikut ini dikutip beberapa definisi spiritualitas yang diberikan. Selman et al (2005) mengatakan bahwa: "Spiritual intelligence is about having a direction in life, and being able to heal ourselves of all the resentment-----; it is thinking of ourselves as an expression of a higher reality" . University of California, Riverside/UCR (http://wellness.ucr.edu/spiritual ) menjelaskan kesehatan spiritual (KS) sebagai:

"---- a personal matter involving values and beliefs that provide a purpose in our lives. It is generally considered to be the search for meaning and purpose in human existence, leading one to strive for a state of harmony with oneself and others while working to balance inner needs with the rest of the world".

Pengertian yang diberikan oleh University of California, Riverside (UCR) ini menekankan upaya mencari makna kehidupan sekaligus membangun dan menjaga keharmonisan hubungan personal dengan yang lain (alam, masyarakat, dan mahluk hidup lainnya). Definisi KS yang lain diberikan oleh Koshuta (2015) sebagai berikut:

"----spiritual health can also consist of more broad concepts, such as hope,

purpose, and peace. Some common criteria that fall within the category of spiritual health include belief in a supreme being, unity with a greater force, a guiding sense of meaning and value, an organized religion, balance, introspection, and meaning".

Sejalan dengan definisi $U C R$, Koshuta juga memberikan definisi yang sangat luas, namun ciri utamanya hampir sama yaitu upaya mencari makna, keseimbangan, introspeksi, dan tujuan kehidupan dengan menumbuhkan keyakinan dan penyatuan dengan kekuatan yang lebih besar (supreme being).

Dengan beberapa contoh definisi KS yang sangat bervariasi seperti di atas, maka McGhee (2015) menyarankan untuk tetap membangun pengertian luas tentang KS, tanpa harus memaksakan definisi tunggal, melainkan dengan mencari unsur-unsur dasar karakteristik yang melekat pada KS tersebut. Atas dasar penjelasan di atas maka dapat disimpulkan bahwa ciri-ciri KS yang nampak sama dari beberapa definisi di atas, antara lain: suatu upaya mencari makna, mengembangkan keharmonisan dengan alam dan pihak lain, dan mengupayakan kemenyatuan sang diri dengan kekuatan universal (God, supreme force).

Teori kesehatan holistik (holistic well-being). Kerangka teori umum tentang kesehatan saat ini telah mengacu pada model kesehatan holistik (sering juga disebut sebagai teori hakikat manusia utuh) yang mencakup enam dimensi: intelektual, fisikal, emosional, sosial, okupasional, dan spiritual dimana terjadi interrelasi dan interaksi antar semua dimensi tersebut (Tunajek, 2012; Schwartz and McCarthy, 2007; Covey, 2005). Covey (2005) menyebutkan hakikat manusia utuh meliputi keseimbangan empat dimensi: kesehatan fisik (KF), kesehatan/kecerdasan intelektual (KI), kesehatan emosional (KE) dan kesehatan spiritual (KS) dengan KS berfungsi sebagai fondasi yang menyatukan. Covey menyatukan aspek emosional dan sosial menjadi KE, sedangkan aspek okupasional 
dihilangkan karena dimensi ini telah tercermin pada keempat dimensi: fisikal, intelektual, emosional, dan spiritual.

KF mencerminkan kondisi kebugaran tubuh yang ditentukan oleh nutrisi yang seimbang, olah raga yang teratur, istirahat yang baik, santai, dan mengelola stress. KI atau IQ merupakan kecerdasan yang sudah dikenal luas selama ini yang berkaitan dengan kapasitas mental/pikiran rasional. KE merupakan kesehatan/kecerdasan rasa yang meliputi kesadaran diri, motivasi diri, pengaturan diri, empati, dan keadilan sosial. KS merupakan kesehatan transendental yang dibangun berdasarkan integritas (menyatu dengan nilai-nilai, nurani, dan hubungan dengan Yang Maha Tak Terbatas), makna (memberikan kontribusi terhadap orang lain dan pada tujuan-tujuan yang bermakna), suara (menyelaraskan pekerjaan kita dengan bakat dan anugrah unik kita). KS berfungsi sebagai fondasi yang menyatukan sekaligus juga mempengaruhi KF, KI, dan KE. Teori kesehatan holistik menggabungkan teori-teori dari berbagai perspektif: teologi, psikologi, sosiologi, dan medikal, sehingga sering juga disebut sebagai teori perawatan (nursing theory) (Leonard \& Carlson, 2016).

Atas dasar penjelasan di atas, maka teori kesehatan holistik atau teori hakikat manusia utuh mencoba menjelaskan kondisi kesehatan manusia sebagai perpaduan dan hasil interaksi serta interkoneksi yang dinamis seluruh dimensi hakikat keberadaan manusia, dengan dimensi spiritual sebagai dimensi yang menyatukan. Sehat dengan demikian dimaknai dalam arti luas - fisik, intelektual, emosional, dan spiritual -, sejalan dengan pengertian sehat menurut $W H O$ (2013) sebagaimana telah diuraikan sebelumnya. Dengan dasar pemikiran dan teori di atas, dan setelah melalui suatu studi literatur yang luas, Fisher (1998), dalam Fernando \& Chowdhury, (2010) menjelaskan bahwa kesehatan spiritual (spiritual well-being) meliputi 4 (empat) domain, yaitu: domain pribadi (personal), komunal (communal), transendental (transcendental), dan lingkungan (environmental). Domain personal mencerminkan bagaimana seseorang berhubungan dengan diri sejati (oneself) yang menyangkut makna, tujuan dan nilai-nilai kehidupan. Domain komunal mengekspresikan kualitas dan kedalaman hubungan intra pribadi, antar sang diri dengan pihak lain, termasuk cinta, keadilan, harapan, dan kepatuhan terhadap kemanusiaan. Domain lingkungan berkaitan dengan kepedulian dan keterkaitan dengan dunia fisik dan biologis, termasuk rasa kagum, dan kemenyatuan dengan lingkungan (alam). Domain transendental menyangkut hubungan sang diri dengan sesuatu (kekuasaan, kekuatan) yang melampaui pemahaman manusia. Sesuatu ini sering disebut: Tuhan, God, cosmic force, atau transcendental reality, dan sejenisnya. Ada dua cara untuk memahami keempat domain kesehatan spiritual versi Fisher, (2010). Pertama, kesehatan spiritual dilihat dari pandangan ideal (ideal spiritual well-being/ISWB), yaitu melihat item-item dimensi kesehatan berdasarkan suatu kondisi pada tingkat yang seharusnya (kondisi ideal). Kedua melihat item-item dimensi kesehatan spiritual berdasarkan kondisi nyata yang dialami dalam sebagian besar kehidupan seseorang. Fisher menyebut kondisi ini sebagai pengalaman/kondisi nyata kesehatan spiritual (lived spiritual well-being/LSWB).

Orientasi Etikal Pembuatan Keputusan. Etika berkenaan dengan pembuatan keputusan apakah suatu tindakan baik atau buruk dan apa yang harus dilakukan tentang hal tersebut jika hal tersebut dinilai buruk (Simanjorang dan Sipayung, 2012). Wang dan Ruhe (2007) mendefinisikan proses keputusan sebagai: "Decision making is one of the basic cognitive processes of human behaviors by which a preferred option or a course of actions is chosen from among a set of alternatives based on certain criteria". Proses keputusan 
dimaknai sebagai suatu proses untuk memilih salah satu dari seperangkat alternatif pilihan yang tersedia dengan menggunakan dasar suatu kriteria tertentu. Dalam ilmu manajemen, istilah proses keputusan sudah sangat dipahami oleh berbagai kalangan, namun modelmodel proses pengambilan keputusan yang dikembangkan lebih banyak ditekankan berdasarkan kriteria dari aspek ekonomi saja, dan sering kali mengabaikan aspek-aspek lain, seperti: etika, sosial, lingkungan, legal, dan sebagainya.

Evans, Levitt, dan Henning. (2012) mengatakan bahwa dalam mengembangkan model-model keputusan etis perlu dipertimbangkan berbagai komponen yang beragam, antara lain budaya, kontekstual, penilaian personal atau profesional, kode etik, hukum dan peraturan, dan sebagainya. Namun Evans, Levitt, dan Henning. (2012) berpandangan bahwa kesadaran diri (self-awareness) merupakan unsur kunci dalam proses pengambilan keputusan yang bersifat etis. Sejalan dengan pandangan Evans, Levitt, dan Henning. (2012), Greeta, Pooja, dan Mishra (2016) mencoba mengidentifikasi faktor-faktor dan variabel-variabel yang mempengaruhi perilaku etis (ethical behavior). Variabel-variabel yang dapat diidentifikasi dibagi menjadi faktor-faktor internal, organisational, dan eksternal. Variabel-variabel internal, antara lain locus of control, orientasi hasil, dan Machiavellianism. Pelatihan etika, kode etik, dan rewarding system merupakan contoh dari variabel-variabel organisasional, sedangkan persaingan usaha, kekuasaan para pemangkukepentingan (stakeholders) dan sistem hukum merupakan variabel-variabel yang bersifat eksternal.

Cara lain untuk menelaah proses keputusan dan perilaku etis adalah dengan memahami model empat komponen proses keputusan yang diajukan oleh Rest (1994), dalam Lincoln dan Elizabeth (2011), yang terdiri dari sensitivitas moral (moral sensitivity), penilaian moral (moral judgment), motivasi/niat moral (moral motivation/intention), dan karakter atau tindakan moral (moral character/action). Sensitivitas atau kesadaran moral adalah kemampuan seseorang dalam mengenali situasi yang mengandung suatu isu moral. Penilaian moral berkaitan dengan perumusan dan pengevaluasian berbagai kemungkinan solusi yang ada dalam menjastifikasi isu moral. Motivasi atau niat moral merujuk pada niat untuk memilih keputusan yang bermoral yang mengalahkan solusi lain yang mengandung suatu nilai yang berlainan. Sedangkan karakter moral mengacu pada perilaku individu yang bersangkutan. Karakter ini melandasi tindakan dalam situasi tertentu yang meliputi keberanian, determinasi, dan kemampuan menaati keputusan bermoral.

Dalam menghadapi persoalan bisnis dan ekonomi yang makin komplek dan mendunia, keputusan yang harus diambil oleh para pimpinan tidak cukup lagi hanya dilihat dari satu aspek saja tetapi harus mempertimbangkan berbagai aspek secara komprehensif termasuk aspek etika.

Teori-Teori Etika. Sedikitnya terdapat tiga perspektif teori yang dapat dijadikan acuan untuk menjelaskan keetisan suatu proses keputusan, yaitu: (1) pendekatan perkembangan penalaran moral (the cognitive development approach), (2) pendekatan disposisi sifat (trait dispositional approaches), dan (3) model interaksi (interactionist model) (Kurtines, 1986, dalam Dinger, 1997). Salah satu teori perkembangan penalaran moral dikembangkan oleh Kohlberg (dalam Agus dan Ardana, 2011) yang menjelaskan bahwa tingkat penalaran moral seseorang berkembang sejalan dengan pertambahan usia orang tersebut. Konsep kunci untuk memahami perkembangan moral Kohlberg ialah adanya perubahan perkembangan perilaku, dari perilaku yang sepenuhnya dikendalikan secara 
eksternal menjadi perilaku yang sepenuhnya dikendalikan secara internal. Kohlberg membagi tiga tingkat kelompok umur: golongan anak-anak (preconventional), golongan remaja (conventional), dan golongan dewasa (post conventional).

Pada tingkat preconventional, sang anak belum memiliki kesadaran moral; oleh karena itu perilaku anak sepenuhnya dikendalikan oleh pihak eksternal (dalam hal ini yang dominan adalah orang tua) melalui hukuman dan ganjaran. Pada tingkat conventional, seseorang mulai menyadari bahwa untuk dapat diterima dalam suatu kelompok atau masyarakat, ia harus juga mengikuti aturan kelompok atau masyarakat dimana ia bergabung. Dalam tahap ini perilaku seseorang ditentukan oleh kombinasi pengaruh internal (kesadaran moral) dan eksternal (aturan sosial). Pada tingkat post conventional, kesadaran atau prinsip moral universal menjadi faktor yang paling dominan dalam mempengaruhi perilaku seseorang.

Teori disposisi sifat (trait theory) mencoba menjelaskan ciri-ciri sifat kepribadian individu yang membedakan individu satu dengan lainnya. Sifat (trait) adalah pola kebiasaan perilaku, pemikiran dan emosi yang relatif bersifat stabil yang membedakan individu satu dengan lainnya (Johnsson, 2009). Walaupun telah banyak sekali sifat-sifat yang dapat diidentifikasi, namun Costa \& Mc Crae (dalam Johnsson, 2009) mengidentifikasi lima (5) sifat utama kepribadian seseorang: extraversion, neuroticism, openness to experience, agreeableness, and conscientiousness. Extraversion cenderung bersifat aktif, mudah bergaul, banyak bicara, optimistik, dan suka berempati. Openness to Experience cenderung imaginatif, penuh perhatian, kreatif, dan mungkin saja memiliki nilai-nilai dan kepercayaan yang tidak konvensional. Agreeableness cenderung baik hati, penolong, peduli orang lain, dapat dipercaya. Conscientiousness cenderung pekerja keras, dapat dipercaya, ambisius, mandiri. Neuroticism cenderung memiliki emosi yang tidak stabil, mudah marah, dan mudah stres.

Dalam konteks model teori interaktif, terdapat 2 (dua) pandangan orientasi etika yang berbeda (sering juga dikenal sebagai ideologi etika/ethical ideology/EI (Dinger,1997). Pertama, suatu pandangan bahwa etika itu bersifat absolut (paham idealisme), yang artinya ada prinsip etika yang berlaku mutlak, dimana saja, kapanpun dan dalam kondisi apapun tanpa memperhatikan konsekuensi dari tindakan tersebut. Pendukung teori ini antara lain Immanuel Kant (yang dikenal dengan teori deontologinya). Kedua, suatu pandangan bahwa etika itu bersifat relatif (paham relativisme), yang artinya etika bersifat fleksibel, tergantung situasi dan kondisi lingkungan yang ada. Pandangan ini menghasilkan teori yang dikenal sebagai teori konsekuentalis; artinya ukuran baik tidaknya suatu keputusan atau tindakan diukur dari seberapa besar dan siapa saja pihak yang memperoleh manfaat (konsekuensi positif) dari tindakan tersebut. Penganut utama paham ini antara lain adalah Joseph Fletcher (Agoes dan Ardana, 2011).

Atas perbedaan paham kedua aliran ini, Schlenker dan Forsyth (1977), dalam Fernando \& Chowdhury (2010), menjelaskan bahwa ada 2 (dua) faktor yang melandasi penalaran mereka. Pertama, adalah derajat keyakinan untuk menerima atau menolak ide aturan moral universal, dan kedua, dikaitkan dengan hasil suatu keputusan dan bagaimana pihak-pihak terkait (pihak eksternal) dipengaruhi. Masyarakat dengan paham relativisme yang tinggi tidak percaya pada aturan moral absolut namun akan memeriksa setiap situasi yang ada, sedangkan masyarakat dengan idealisme yang tinggi yakin bahwa tindakantindakan yang dilandasi prinsip moral universal akan berdampak positif dan tidak setuju bahwa harus ada pihak-pihak yang dirugikan untuk mencapai suatu tujuan tertentu. 
Kaitan antara Variabel. Fernando dan Chowdhury (2010) meneliti keterkaitan SWB dengan EDM dengan menyebarkan 6.000 kuesioner secara elektronik kepada para eksekutif perusahaan publik di Australia. Terdapat dua orientasi etikal pembuatan keputusan (ethical orientation of decision making / EDM) yang diteliti, yaitu orientasi etikal ideal $(I E D M)$ dan orientasi etikal relatif (REDM). Responden yang mengisi sebanyak 1.910 kuesoner. Hasil penelitiannya menunjukkan bahwa ada keterkaitan kuat $I S W B$ dengan IEDM, namun terhadap $L S W B$ dengan REDM, terdapat pula keterkaitan meskipun level keterkaitannya tidak cukup signifikan.

Amalia dan Yunizar (2007) meneliti pengaruh spiritualitas di tempat kerja terhadap perilaku. Hasil penelitiannya menunjukkan bahwa spritualitas yang baik akan menyebabkan sikap kerja dan tindakan karyawan yang baik (etis) pula. Rochmah dan Prihatiningtias (2012) melakukan penelitian apakah $I Q$ (kecerdasan intelektual) dan $S Q$ (kecerdasan spiritual) dapat digunakan untuk memprediksi persepsi mahasiswa akuntansi mengenai keetisan praktek earnings management. Hasil penelitian mereka menunjukkan bahwa mahasiswa yang memiliki $I Q$ dan $S Q$ yang tinggi tidak hanya menggunakan logika tetapi juga kata hati (sifat kesadaran diri) untuk berfikir, menganalisis suatu kejadian, dan mengambil suatu keputusan. Dikatakan bahwa makin tinggi $I Q$ dan $S Q$ mahasiswa, makin kuat keyakinan responden bahwa praktik earnings management adalah tindakan yang tidak etis.

Agbim, Ayatse, dan Oriarewo (2013) meneliti keterkaitan spiritualitas, perilaku etis, dan bisnis etis. Data diperoleh dari 152 responden, kemudian setelah dianalisis menggunakan korelasi Person's P roduct M oment, menemukan bahwa terdapat keterkaitan erat antara karakteristik perilaku, nilai-nilai spiritual, perilaku etis dan bisnis etis. Dengan menginternalisasikan dan mempraktikkan nilai-nilai spiritual oleh para pelaku bisnis terbukti dapat menumbuhkan perilaku dan kesadaran etis dalam proses pengambilan keputusan bisnis. McGhee dan Grant (2008) mengkaji spiritualitas dengan perilaku etis dan mengemukakan bahwa orang-orang yang bersifat spiritual akan menjadi orang-orang yang bertindak etis sehingga akan memberikan manfaat penting bagi organisasi dimana mereka berada.

Kaitan Kesehatan Spiritual Ideal (ISWB) dengan Orientasi Etikal Idealis dalam Pembuatan Keputusan (IEDM). Spiritualitas menyangkut kognisi etis dan menjadi faktor penting dalam menentukan bagaimana seseorang mempersepsikan keetisan dari suatu situasi. Peningkatan kesadaran spiritual akan meningkatkan persepsi kritis tentang praktik-praktik bisnis yang tidak etis. Hal ini menyiratkan bahwa spiritualitas yang lebih tinggi akan menuntun pada kepedulian terhadap keputusan yang lebih etis (Giascalone dan Jurkiewicz, 2003). Jadi kesehatan spiritual yang dipandang sebagai hasil dari pengalaman spiritual, seharusnya juga mempengaruhi orientasi keputusan, namun pengaruhnya mungkin berbeda untuk pihak penganut paham etika-idealis dengan pihak penganut paham etika-relatif (Fernando dan Chowdhury, 2010).

Kaitan Pengalaman Kesehatan Spiritual $(L S W B)$ dengan Orientasi Etikal Relatif dalam Pembuatan Keputusan (REDM). Dalam menjalankan praktik bisnis sehari-hari, keetisan keputusan yang diambil oleh seorang eksekutif korporasi sangat dipengaruhi oleh kombinasi antara seberapa besar ketebalan rasa spiritualitas dalam diri yang tumbuh dari pengalaman spiritual sehari-hari dengan pengalaman konteks lingkungan bisnis yang dihadapi. Kondisi riil dalam menjalankan bisnis ini, dapat saja memunculkan salah satu 
dari empat golongan manusia sebagaimana dikatakan oleh Forsyth (1980), yaitu absolutisme (idealisme tinggi, relativisme rendah), situationisme (idealisme tinggi, relativisme tinggi), subjectivisme (idealisme rendah, relativisme tinggi) dan exceptionalisme (idealisme rendah, relativisme rendah). Sebagaimana dikatakan oleh Fernando dan Chowdhury (2010), hubungan antara LSWB dengan REDM masih sering diperdebatkan.

Kerangka Pemikiran \& Pengembangan Hipotesis. Dalam kaitan ISWB dengan IEDM diharapkan berkaitan secara positif dimana orang-orang yang memiliki tingkat kesehatan spiritual yang mendekati ideal, umumnya juga menganut ideologi atau paham etika idealis yang tinggi saat pembuatan keputusan. Ini sejalan dengan teori kesehatan holistik atau teori hakikat manusia utuh dimana kesehatan spiritual merupakan fondasi yang mempengaruhi secara positif kesehatan fisik, intelektual dan emosional. Mereka yang memiliki kesehatan spiritual tinggi (kesehatan spiritual ideal) akan mempunyai keyakinan kuat tentang prinsip-prinsip moral universal, sangat besar kepeduliannya terhadap kesejahteraan pihak lain dan kelestarian alam, serta merasa menjadi bagian dari keberadaan yang lebih besar. Atas dasar penalaran ini, maka dikembangkan hipotesis alternatif 1 sebagai berikut:

Ha1: Ada keterkaitan antara Kesehatan Spiritual Ideal (Ideal Spiritual Well-Being/ISWB), baik secara keseluruhan maupun masing-masing domain: Ideal Communal, Ideal Personal, Ideal Transcendental, dan Ideal Environmental dengan Orientasi Etikal Idealis Pembuatan Keputusan (Ideal Ethical Orientation of Decision Making/IEDM).

Dalam kaitan Pengalaman Kesehatan Spiritual (Lived Spiritual Well-Being/LSWB) dengan Orientasi Etikal Relatif Pembuatan Keputusan (Relative Ethical Orientation of Decision Making/REDM) diharapkan juga berkaitan secara positif dimana seseorang yang memiliki pengalaman kesehatan spiritual yang tinggi, umumnya memiliki orientasi etikal relatif yang tinggi dalam pembuatan keputusan. Walaupun masih belum ada landasan teori maupun hasil-hasil temuan penelitian sebelumnya yang cukup meyakinkan untuk menjelaskan fenomena hubungan antara Pengalaman Kesehatan Spiritual dengan Orientasi Etikal-Relatif Pembuatan Keputusan tersebut. Oleh karena itu, penelitian ini ingin menginvestigasi keterkaitan antara $L S W B$ dengan REDM.

Ha2: Ada keterkaitan antara $L S W B$ baik secara keseluruhan, maupun dari masing-masing domain: Lived Communal, Lived Personal, Lived Transcendental, dan Lived Environmental) dengan REDM.

Terdapat 2 (dua) model dalam penelitian ini. Pertama (hipotesis 1), menguji keterkaitan (korelasi) Kesehatan Spiritual Idealis (ISWB) secara keseluruhan maupun masing-masing domain: ICSWB, IPSWB, ITSWB, dan IESWB dengan Orientasi Etikal-Idealis Pembuatan Keputusan (IEDM). Kedua (hipotesis 2), menguji keterkaitan Pengalaman Kesehatan Spiritual $(L S W B)$ baik secara keseluruhan, maupun dari masing-masing domain: $L C S W B$ ), $L P S W B), L T S W B$, dan $L E S W B$ dengan Orientasi Etikal-Relatif Pembuatan Keputusan (REDM). 


\section{Model Penelitian}

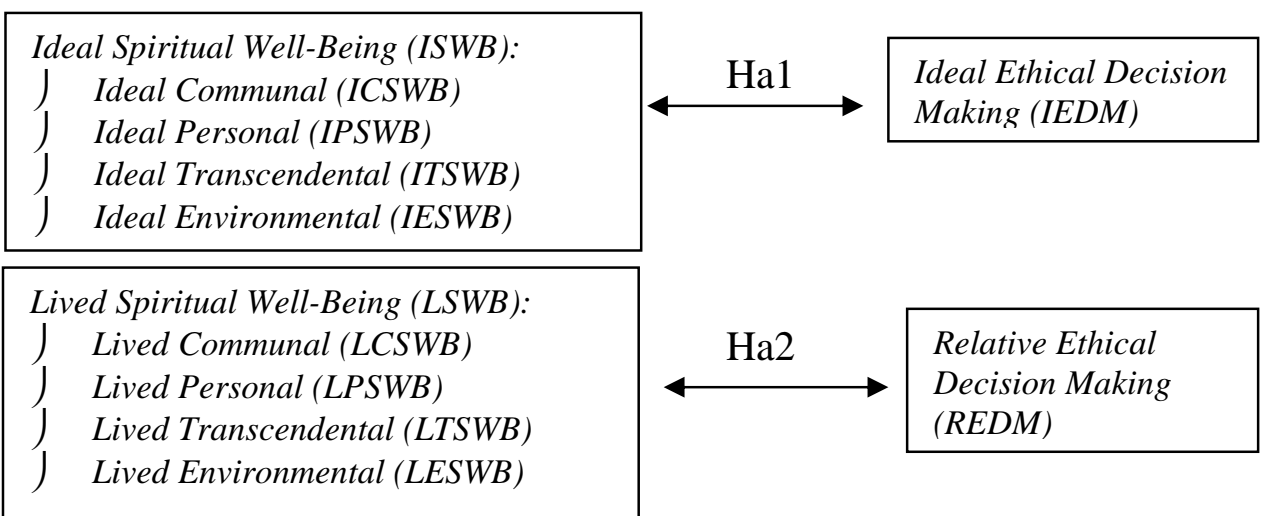

Gambar 1. Model Penelitian Keterkaitan Kesehatan Spiritual dengan Orientasi Etikal Pembuatan Keputusan

\section{METODE}

Populasi dan Sampel. Populasi dalam penelitian ini adalah seluruh eksekutif organisasi, perusahaan publik (listing companies) dan perusahaan privat (non listing companies) yang beralamat di Jakarta dan sekitarnya. Pemilihan responden sebagai sampel didasarkan atas convinience sampling; responden yang dipilih adalah para eksekutif yang bersedia untuk mengisi dan mengembalikan kuesioner. Kuesioner disebar secara langsung dan juga melalui google form. Jumlah kuesioner yang dikirim 614, gagal kirim 140, terkirim 474, tidak menjawab 364, dan yang menjawab 110. Dari 110 jawaban ada yang tidak lengkap menjawab 13 sehingga sampel yang diolah 97 responden. Profil responden yang dijadikan sampel penelitian ini dapat dilihat pada Tabel 1.

Tabel 1. Profil Responden

\begin{tabular}{lcc}
\hline \multicolumn{1}{c}{ Responden } & Sampel & \% Sampel \\
\hline Berdasarkan klasifikasi & & \\
organisasi/perusahaan: & & \\
$\quad$ Perusahaan publik & 8 & $8,25 \%$ \\
Perusahaan privat & 76 & $78,35 \%$ \\
Tidak Menjawab & $\underline{13}$ & $\underline{13,40 \%}$ \\
$\quad$ Total & 97 & $100 \%$ \\
Berdasarkan Gender: & 51 & $52,58 \%$ \\
$\quad$ Pria & 42 & $43,30 \%$ \\
$\quad$ Wanita & $\underline{4}$ & $4,12 \%$ \\
$\quad$ Tidak menjawab & 97 & $100 \%$ \\
$\quad$ Total = & 54 & $55,67 \%$ \\
Berdasarkan Status: & 39 & $40,21 \%$ \\
Menikah & $\underline{4}$ & $4,12 \%$ \\
Belum Menikah & 97 & $100 \%$ \\
Tidak Menjawab & & \\
\hline
\end{tabular}


Variabel dalam setiap pengujian penelitian ini terdiri dari dua variabel: Ethical Orientation of Decision Making dan Spiritual Well-Being, sehingga jumlah sampel minimum penelitian ini adalah 60 responden yang diambil dari 30 responden di perusahaan yang terdaftar di BEI (listed companies) dan 30 responden di perusahaan yang tidak terdaftar, dan organisasi lainnya. Dengan harapan tingkat pengembalian angket diestimasi $25 \%$ maka penelitian ini mendistribusikan 240 angket dimana 120 angket didistribusikan ke listed companies dan 120 angket didistribusikan ke non-listed companies dan organisasi lainnya. Kriteria penentuan sampel yang dijadikan responden penelitian ini adalah: (1) profesional / eksekutif / manajer yang membuat keputusan bisnis atau organisasi, (2) responden sudah bekerja lebih dari 1 tahun sebelum tahun penelitian ini dilakukan, dan (3) responsen bersedia mengisi dan mengembalikan kuesioner.

Variabel Penelitian. Variabel pertama penelitian ini terdiri dari orientasi etikal pembuatan keputusan (ethical orientation of decision making) yang terdiri dari orientasi etikal ideal pembuatan keputusan (ideal ethical orientation of decision making/IEDM) dan orientasi etikal relatif pembuatan keputusan (relative ethical orientation of decision making/REDM). Mengacu pada model Forsyth (dalam Fernando \& Chowdhury, 2010), idealism diukur dengan delapan butir pertanyaan, dan relativism diukur dengan tujuh butir pertanyaan, sehingga totalnya ada 15 pertanyaan. Seluruh angket diukur dengan skala Likert dengan skor 1 (sangat tidak setuju) sampai dengan 5 (sangat setuju).

Variabel kedua penelitian ini yaitu kesehatan spiritual (spiritual well-being/SWB) mengacu pada model Fisher (1998), dalam Fernando \& Chowdhury (2010), yang diukur dengan 4 (empat) domain atau dimensi, dan masing-masing domain diukur dengan 5 (lima) butir pertanyaan, dimana ke-empat domain atau dimensi tersebut adalah: Communal, Personal, Transcendental, dan Environmental. Ke-empat domain dipecah ke dalam dua kondisi, yaitu: (1) kesehatan spiritual ideal (Ideal Spiritual Well-Being/ISWB) dan (2) pengalaman kesehatan spiritual (Lived Spiritual Well-Being/LSWB), sehingga ada 2 X 4 X $5=40$ pertanyaan. Seluruh angket diukur dengan skala Likert dengan skor 1 (sangat tidak setuju) sampai dengan 5 (sangat setuju).

Operasionalisasi Variabel. Di bawah ini disajikan Tabel 2 yang menggambarkan operasionalisasi variabel penelitian ini.

Tabel 2. Operasionalisasi Variabel Penelitian

\begin{tabular}{|c|c|c|c|c|c|}
\hline No. & Variabel & Dimensi & $\begin{array}{c}\text { Butir } \\
\text { kuesioner }\end{array}$ & Skala & Sumber Referensi \\
\hline 1 & $\begin{array}{l}\text { Ideal Ethical } \\
\text { Decision making } \\
(\text { IEDM) }\end{array}$ & & I1 s/d I8 & Interval & $\begin{array}{l}\text { Forsyth, dalam } \\
\text { Fernando \& Chowdhu } \\
\text { ry (2010) }\end{array}$ \\
\hline 2 & $\begin{array}{l}\text { RelativeEthical } \\
\text { Decision Making } \\
(\text { REDM })\end{array}$ & & R1 s/d R7 & Interval & $\begin{array}{l}\text { Forsyth, dalam } \\
\text { Fernando \& Chowdhu } \\
\text { ry (2010) }\end{array}$ \\
\hline 3 & $\begin{array}{l}\text { Ideal Spiritual } \\
\text { Well-Being } \\
(I S W B)\end{array}$ & $\begin{array}{l}\text { Ideal Communal, } \\
\text { Ideal Personal } \\
\text { Ideal } \\
\text { Transcendental } \\
\text { Ideal } \\
\text { Environmental }\end{array}$ & $\begin{array}{l}\text { IC1 s/d IC5 } \\
\text { IP1 s/d IP5 } \\
\text { IT1 s/d IT5 } \\
\text { IE1 s/d IE5 }\end{array}$ & Interval & $\begin{array}{l}\text { Fisher, dalam } \\
\text { Fernando } \\
\text { Chowdhury (2010) }\end{array}$ \\
\hline
\end{tabular}


Ardana, Sugiarto dan Yuniarwati: Keterkaitan Kesehatan Spiritual dan Orientasi...

\begin{tabular}{|c|c|c|c|c|c|}
\hline No. & Variabel & Dimensi & $\begin{array}{c}\text { Butir } \\
\text { kuesioner }\end{array}$ & Skala & Sumber Referensi \\
\hline 1 & $\begin{array}{l}\text { Ideal Ethical } \\
\text { Decision making } \\
(\text { IEDM) }\end{array}$ & & I1 s/d I8 & Interval & $\begin{array}{l}\text { Forsyth, dalam } \\
\text { Fernando \& Chowdhu } \\
\text { ry (2010) }\end{array}$ \\
\hline 4 & $\begin{array}{l}\text { Lived Spiritual } \\
\text { Well-Being } \\
(\text { LSWB })\end{array}$ & $\begin{array}{l}\text { Lived Communal, } \\
\text { Lived Personal } \\
\text { Lived } \\
\text { Transcendental } \\
\text { Lived } \\
\text { Environmental }\end{array}$ & $\begin{array}{l}\text { LC1 s/d } \\
\text { LC5 } \\
\text { LP1 s/d } \\
\text { LP5 } \\
\text { LT1 s/d } \\
\text { LT5 } \\
\text { LE1 s/d } \\
\text { LE5 }\end{array}$ & Interval & $\begin{array}{l}\text { Fisher, dalam } \\
\text { Fernando } \\
\text { Chowdhury (2010) }\end{array}$ \\
\hline
\end{tabular}

Sebelum dilakukan pengujian korelasi, terlebih dahulu dilakukan pengujian reliabilitas dan validitas model pengukuran kesehatan spiritual (model Fisher) dan model pengukuran orientasi etikal keputusan (model Forsyth). Uji validitas dilakukan dengan Confirmatory Factor Analysis (CFA), sedangkan uji reliabilitas menggunakan Alpha Cronbach's. Teknik pengujian korelasi menggunakan analisis korelasi Pearson (jika datanya terdistribusi normal) atau analisis Spearman's Rho (jika datanya tidak terdistribusi normal). Oleh karena itu terlebih dahulu dilakukan uji normalitas data sebelum dilakukan uji korelasi. Data penelitian diolah dengan menggunakan SPSS versi 22.

\section{HASIL DAN PEMBAHASAN}

Model penelitian pertama: keterkaitan ISWB dengan IEDM. Sebelum dilakukan pengujian keterkaitan ISWB dengan IEDM, terlebih dahulu dilakukan pengujian normalitas data dan instrumen penelitian. Dari hasil pengujian normalitas dapat disimpulkan bahwa data yang berkaitan dengan ISWB dan IEDM telah memenuhi persyaratan normalitas data. Pengujian instrumen penelitian atau model pengukuran dilakukan dalam bentuk uji validitas dan reliabilitas.

KMO-MSA untuk dimensi ICSWB adalah 0.807, masih di atas kriteria sebesar 0.5; sedangkan signifikansi Bartlett's test adalah 0.000, masih jauh di bawah 0.05. Jika dilihat dari nilai anti-image correlation masing-masing indikator (ICSWB1, ICSWB2, ICSWB3, ICSWB4, ICSWB5), semua menunjukkan angka di atas 0.5. Ini berarti bahwa seluruh indikator yang mengukur dimensi ICSWB adalah valid. Pengujian validitas dimensi IPSWB menunjukkan bahwa KMO-MSA untuk dimensi IPSWB adalah 0.708, masih di atas kriteria sebesar 0.5; sedangkan signifikansi Bartlett's test adalah 0.000, masih jauh di bawah 0.05. Jika dilihat dari anti-image correlation masing-masing indikator (IPSWB1 s/d IPSWB5) semua menunjukkan angka di atas 0.5 . Ini berarti bahwa seluruh indikator yang mengukur dimensi IPSWB adalah valid. Pengujian validitas dimensi ITSWB menunjukkan bahwa KMO-MSA untuk dimensi ITSWB adalah 0.719, masih di atas kriteria sebesar 0.5; sedangkan signifikansi Bartlett's test adalah 0.000, masih jauh di bawah 0.05. Jika dilihat dari anti-image correlation masing-masing indikator (ITSWB1 s/d ITSWB5), semua menunjukkan angka di atas 0.5 . Ini berarti bahwa seluruh indikator yang mengukur dimensi ITSWB adalah valid. Pengujian validitas dimensi IESWB menunjukkan bahwa KMO-MSA untuk dimensi IESWB adalah 0.819, masih di atas kriteria sebesar 0.5; sedangkan signifikansi Bartlett's test adalah 0.000, masih jauh di bawah 0.05. Jika dilihat 
dari anti-image correlation masing-masing indikator (IESWB1 s/d IESWB5), semua menunjukkan angka di atas 0.5 . Ini berarti bahwa seluruh indikator yang mengukur dimensi IESWB adalah valid. KMO-MSA untuk variabel atau konstrak $I S W B$ adalah 0.720 , masih di atas kriteria sebesar 0.5; sedangkan signifikansi Bartlett's test adalah 0.000, masih jauh di bawah 0.05. Jika dilihat dari nilai anti-image correlation masing-masing dimensi (ICSWB, IPSWB, ITSWB, dan IESWB), semua menunjukkan angka di atas 0.5. Ini berarti bahwa konstrak $I S W B$ adalah valid. KMO-MSA untuk konstrak atau variabel IEDM adalah 0.767, masih di atas kriteria sebesar 0.5; sedangkan signifikansi Bartlett's test adalah 0.000 , masih jauh di bawah 0.05 . Jika dilihat dari anti-image correlation masingmasing butir pertanyaan (IEDM1 s/d IEDM8), semua menunjukkan angka di atas 0.5 . Ini berarti bahwa seluruh indikator atau butir-butir pertanyaan yang mengukur konstrak/variabel IEDM adalah valid.

Suatu instrumen dikatakan reliable jika hasil pengukuran dengan instrumen tersebut bersifat konsisten. Uji reliabilitas model pengukuran konstrak ISWB dan IEDM menggunakan uji Cronbach's Alpha. Suatu instrumen dikatakan reliable jika nilai Cronbach's Alpha minimal adalah 0.6 (Ghozali, 2009). Konstrak ISWB terdiri dari 4 (empat) dimensi (ICSWB, IPSWB, ITSWB, dan IESWB) dan setiap dimensi ISWB terdiri dari 5 (lima) butir pertanyaan. Nilai Cronbach's Alpha dimensi dan konstrak ISWB masing-masing adalah: ICSWB (0.756), IPSWB (0.719), ITSWB (0.862), IESWB (0.832) dan $I S W B$ (0.781). Dari hasil pengujian reliabilitas di atas dapat disimpulkan bahwa instrumen penelitian untuk mengukur variabel/konstrak ISWB dan dimensi ISWB (ICSWB, $I P S W B, I T S W B, I E S W B$ ) telah cukup reliable karena semua nilai Cronbach's Alpha masih di atas ketentuan minimal 0.6.

Hasil pengukuran reliabilitas konstrak IEDM yang terdiri dari 8 (delapan) butir pertanyaan menunjukkan nilai Cronbach's Alpha sebesar 0.813 , ini berarti instrumen penelitian untuk mengukur konstrak IEDM juga telah cukup reliable karena nilai Cronbach's Alpha masih di atas ketentuan minimal sebesar 0.6.

Pengujian keterkaitan atau korelasi ISWB dengan IEDM. Hasil pengujian korelasi $I S W B$ dengan IEDM dapat dilihat pada Tabel 3.

Tabel 3. UJI KORELASI ISWB-IEDM

\begin{tabular}{|c|c|c|c|c|c|c|c|}
\hline \multicolumn{8}{|c|}{ Correlations } \\
\hline \multirow{3}{*}{ ICSWB } & & ICSWB & IPSWB & ITSWB & IESWB & ISWB & IEDM \\
\hline & $\begin{array}{l}\text { Pearson } \\
\text { Correlation }\end{array}$ & 1 &, $657^{* *}$ & , $499^{* *}$ &, $357^{* *}$ &, $754^{* *}$ &, $523^{* *}$ \\
\hline & Sig. (2-tailed) & & ,000 & ,000 & ,000 & ,000 & ,000 \\
\hline \multirow{3}{*}{ IPSWB } & $\mathrm{N}$ & 97 & 97 & 97 & 97 & 97 & 97 \\
\hline & $\begin{array}{l}\text { Pearson } \\
\text { Correlation }\end{array}$ &, $657^{* *}$ & 1 & $486^{* *}$ &, $532^{* *}$ &, $816^{* *}$ &, $504^{* *}$ \\
\hline & Sig. (2-tailed) & ,000 & & ,000 & ,000 & 000 & ,000 \\
\hline \multirow[b]{2}{*}{ ITSWB } & $\mathrm{N}$ & 97 & 97 & 97 & 97 & 97 & 97 \\
\hline & $\begin{array}{l}\text { Pearson } \\
\text { Correlation }\end{array}$ & ,499** & ,486** & 1 &, $469^{* *}$ &, $791^{* *}$ &, $363^{* *}$ \\
\hline \multirow[b]{3}{*}{ IESWB } & Sig. (2-tailed) & ,000 & 000 & &, 000 & 000 & ,000 \\
\hline & $\mathrm{N}$ & 97 & 97 & 97 & 97 & 97 & 97 \\
\hline & $\begin{array}{l}\text { Pearson } \\
\text { Correlation }\end{array}$ &, $357^{* *}$ &, $532^{* *}$ &, $469^{* *}$ & 1 &, $790^{* *}$ &, $482^{* *}$ \\
\hline
\end{tabular}




\begin{tabular}{rlrrrrrr}
\hline \hline \multirow{5}{*}{ ISWB } & Sig. (2-tailed) &, 000 &, 000 &, 000 & &, 000 &, 000 \\
& N & 97 & 97 & 97 & 97 & 97 & 97 \\
& Pearson &, $754^{* *}$ &, $816^{* *}$ &, $791^{* *}$ &, $790^{* *}$ & 1 &, $588^{* *}$ \\
& Correlation &, 000 &, 000 &, 000 &, 000 & &, 000 \\
& Sig. (2-tailed) & 97 & 97 & 97 & 97 & 97 & 97 \\
& N &, $523^{* *}$ &, $504^{* *}$ &, $363^{* *}$ &, $482^{* *}$ &, $588^{* *}$ & 1 \\
IEDM & Pearson &, 000 &, 000 &, 000 &, 000 &, 000 & \\
& Correlation & 97 & 97 & 97 & 97 & 97 & 97 \\
& Sig. (2-tailed) & N & 97 & & &
\end{tabular}

Dari Tabel 3 dapat diketahui bahwa nilai korelasi konstrak ISWB dengan konstrak IEDM adalah positif sebesar 0.588, dan signifikan pada level 0.01. Bila dilihat dari masing-masing dimensi $I S W B$, maka korelasi dimensi ICSWB dengan konstrak IEDM adalah positif sebesar 0.523 , dan signifikan pada level 0.01 ; korelasi IPSWB dengan konstrak IEDM adalah positif sebesar 0.504 dan signifikan pada level 0.01 ; korelasi ITSWB dengan konstrak IEDM adalah positif sebesar 0.363 , dan signifikan pada level 0.01 , serta korelasi IESWB dengan konstrak IEDM adalah positif sebesar 0.482 dan signifikan pada level 0.01. Dari hasil pengujian korelasi di atas, dapat disimpulkan bahwa Ha1: ISWB baik secara keseluruhan maupun masing-masing dimensi: ICSWB, IPSWB, $I T S W B$, dan IESWB berkaitan secara positif dengan IEDM dan semua signifikan pada level 0.01. Oleh karena itu Ha1 diterima.

Model penelitian kedua: Keterkaitan $L S W B$ dengan REDM. Sebelum dilakukan pengujian keterkaitan $L S W B$ dengan $R E D M$, terlebih dahulu dilakukan pengujian normalitas data dan instrumen penelitian. Dari hasil pengujian normalitas data dapat disimpulkan bahwa data yang berkaitan dengan $L S W B$ dan REDM telah memenuhi persyaratan normalitas data. Pengujian instrumen penelitian atau model pengukuran dilakukan dalam bentuk uji validitas dan reliabilitas.

KMO-MSA untuk dimensi $L C S W B$ adalah 0.852, masih di atas kriteria sebesar 0.5; sedangkan signifikansi Bartlett's test adalah 0.000, masih jauh di bawah 0.05. Jika dilihat dari nilai anti-image correlation masing-masing indikator (LCSWB1, LCSWB2, LCSWB3, $L C S W B 4, L C S W B 5)$, semua menunjukkan angka di atas 0.5. Ini berarti bahwa seluruh indikator yang mengukur dimensi $L C S W B$ adalah valid. Pengujian validitas dimensi IPSWB menunjukkan bahwa KMO-MSA untuk dimensi IPSWB adalah 0.833, masih di atas kriteria sebesar 0.5; sedangkan signifikansi Bartlett's test adalah 0.000, masih jauh di bawah 0.05. Jika dilihat dari anti-image correlation masing-masing indikator (LPSWB1 $s / d$ LPSWB5) semua menunjukkan angka di atas 0.5. Ini berarti bahwa seluruh indikator yang mengukur dimensi $L P S W B$ adalah valid. Pengujian validitas dimensi $L T S W B$ menunjukkan bahwa KMO-MSA untuk dimensi $L T S W B$ adalah 0.668 , masih di atas kriteria sebesar 0.5; sedangkan signifikansi Bartlett's test adalah 0.000, masih jauh di bawah 0.05. Jika dilihat dari anti-image correlation masing-masing indikator (LTSWB1 $s / d$ LTSWB5), semua menunjukkan angka di atas 0.5. Ini berarti bahwa seluruh indikator yang mengukur dimensi $L T S W B$ adalah valid. Pengujian validitas dimensi $L E S W B$ menunjukkan bahwa KMO-MSA untuk dimensi $L E S W B$ adalah 0.836, masih di atas kriteria sebesar 0.5; sedangkan signifikansi Bartlett's test adalah 0.000, masih jauh di bawah 0.05. Jika dilihat dari anti-image correlation masing-masing indikator (LESWB1 
s/d LESWB5), semua menunjukkan angka di atas 0.5. Ini berarti bahwa seluruh indikator yang mengukur dimensi $L E S W B$ adalah valid. KMO-MSA untuk variabel atau konstrak LSWB adalah 0.790, masih di atas kriteria sebesar 0.5; sedangkan signifikansi Bartlett's test adalah 0.000 , masih jauh di bawah 0.05 . Jika dilihat dari nilai anti-image correlation masing-masing dimensi ( $L C S W B, L P S W B$, LTSWB, dan LESWB), semua menunjukkan angka di atas 0.5 . Ini berarti bahwa konstrak $L S W B$ adalah valid. Pengujian validitas konstrak REDM juga dapat dilihat paga Tabel 4-5. KMO-MSA untuk konstrak atau variabel $R E D M$ adalah 0.865 , masih di atas kriteria sebesar 0.5 ; sedangkan signifikansi Bartlett's test adalah 0.000, masih jauh di bawah 0.05. Jika dilihat dari anti-image correlation masing-masing butir pertanyaan (REDM1 s/d REDM7), semua menunjukkan angka di atas 0.5 . Ini berarti bahwa seluruh indikator atau butir-butir pertanyaan yang mengukur konstrak/variabel REDM adalah valid.

Suatu instrumen dikatakan reliable jika hasil pengukuran dengan instrumen tersebut bersifat konsisten. Uji reliabilitas model pengukuran konstrak LSWB dan REDM menggunakan uji Cronbach's Alpha. Suatu instrumen dikatakan reliable jika nilai Cronbach's Alpha minimal adalah 0.6. Konstrak $L S W B$ terdiri dari 4 (empat) dimensi ( $L C S W B, L P S W B, L T S W B$, dan $L E S W B$ ) dan setiap dimensi $L S W B$ terdiri dari 5 (lima) indikator atau butir pertanyaan. Nilai Cronbach's Alpha dimensi dan konstrak $L S W B$ masing-masing adalah: LCSWB (0.895), LPSWB (0.898), LTSWB (0.862), LESWB (0.866) dan $L S W B$ (0.878). Dari hasil pengujian reliabilitas di atas dapat disimpulkan bahwa instrumen penelitian untuk mengukur variabel/konstrak $L S W B$ dan dimensi $L S W B$ ( $L C S W B, L P S W B, L T S W B, L E S W B$ ) telah cukup reliable karena semua nilai Cronbach's Alpha masih di atas ketentuan minimal 0.6. Hasil pengukuran reliabilitas konstrak REDM yang terdiri dari 7 (tujuh) indikator/butir pertanyaan menunjukkan nilai Cronbach's Alpha sebesar 0.865. Ini berarti bahwa instrumen penelitian untuk mengukur konstrak REDM juga telah cukup reliable karena nilai Cronbach's Alpha masih di atas ketentuan minimal sebesar 0.6.

Pengujian keterkaitan $L S W B$ dengan REDM. Hasil pengujian korelasi LSWB dengan REDM dapat dilihat pada Tabel 4. Dari Tabel 4 dapat diketahui bahwa nilai korelasi konstrak $L S W B$ dengan konstrak REDM adalah positif sebesar 0.308, dan signifikan pada level 0.01. Bila dilihat dari masing-masing dimensi $L S W B$, maka korelasi dimensi $L C S W B$ dengan konstrak REDM adalah positif sebesar 0.263 , dan signifikan pada level 0.01 ; korelasi $L P S W B$ dengan konstrak REDM adalah positif sebesar 0.205 dan signifikan pada level 0.05; korelasi $L T S W B$ dengan konstrak REDM adalah positif sebesar 0.181, namun tidak signifikan, serta korelasi $L E S W B$ dengan konstrak REDM adalah positif sebesar 0.392 dan signifikan pada level 0.01. Dari hasil pengujian korelasi di atas, dapat disimpulkan bahwa hipotesis $\mathrm{Ha} 2$ tidak seluruhnya diterima. Secara keseluruhan konstrak/variabel $L S W B$ berkaitan secara positif dan signifikan dengan REDM pada level 0.01. Dalam hal ini, Ha2 diterima. Namun dalam pengujian keterkaitan dimensi-dimensi $L S W B$ ( $L C S W B, L P S W B, L T S W B, L E S W B$ ) dengan REDM, terdapat perbedaan hasil pengujian untuk masing-masing dimensi $L S W B$ tersebut.

Hasil pengujian masing-masing dimensi $L S W B$ dengan $R E D M$ adalah sebagai berikut: (a) ada keterkaitan secara positif antara dimensi $L C S W B$ dengan REDM dan signifikan pada level 0.01, (b) ada keterkaitan secara positif antara dimensi $L E S W B$ dengan $R E D M$ dan signifikan pada level 0.01 , (c) ada keterkaitan secara positif antara dimensi $L P S W B$ dengan REDM, dan signifikan pada level 0.05 dan (d) tetap ada 
keterkaitan secara positif antara dimensi $L T S W B$ dengan REDM walaupun keterkaitannya tidak cukup signifikan. Pada pengujian keterkaitan $L C S W B, L P S W B$, dan $L E S W B$ dengan REDM, Ha2 diterima, sedangkan pada pengujian keterkaitan LTSWB dengan REDM, sebagian Ha2 diterima (dalam hal ini terdapat keterkaitan LTSWB dengan REDM secara positif) dan sebagian $\mathrm{Ha} 2$ ditolak (dalam hal ini keterkaitan LTSWB dengan REDM tidak cukup signifikan).

\begin{tabular}{|c|c|c|c|c|c|c|c|}
\hline & & 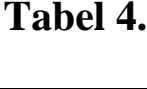 & Correlati & ons & 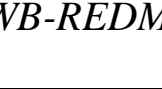 & & \\
\hline & & LCSWB & LPSWB & LTSWB & LESWB & LSWB & REDM \\
\hline LCSWB & $\begin{array}{l}\text { Pearson } \\
\text { Correlation }\end{array}$ & 1 &, $810^{* *}$ &, $666^{* *}$ &, $606^{* *}$ &, $885^{* *}$ &, $263^{* *}$ \\
\hline & Sig. (2-tailed) & & 000 & ,000 & ,000 & ,000 & ,009 \\
\hline & $\mathrm{N}$ & 97 & 97 & 97 & 97 & 97 & 97 \\
\hline LPSWB & $\begin{array}{l}\text { Pearson } \\
\text { Correlation }\end{array}$ &, $810^{* *}$ & 1 &, $607^{* *}$ &, $598^{* *}$ &, $869^{* *}$ &, $205^{*}$ \\
\hline & Sig. (2-tailed) & ,000 & & ,000 & ,000 & ,000 & ,044 \\
\hline & $\mathrm{N}$ & 97 & 97 & 97 & 97 & 97 & 97 \\
\hline & & LCSWB & LPSWB & LTSWB & LESWB & LSWB & REDM \\
\hline LTSWB & $\begin{array}{l}\text { Pearson } \\
\text { Correlation }\end{array}$ &, $666^{* *}$ &, $607^{* *}$ & 1 &, $626^{* *}$ &, $845^{* *}$ & ,181 \\
\hline & Sig. (2-tailed) & ,000 & ,000 & & ,000 & ,000 & ,076 \\
\hline & $\mathrm{N}$ & 97 & 97 & 97 & 97 & 97 & 97 \\
\hline LESWB & $\begin{array}{l}\text { Pearson } \\
\text { Correlation }\end{array}$ &, $606^{* *}$ &, $598^{* *}$ &, $626^{* *}$ & 1 &, $838^{* *}$ &, $392^{* *}$ \\
\hline & Sig. (2-tailed) & ,000 &, 000 & ,000 & & ,000 & ,000 \\
\hline & $\mathrm{N}$ & 97 & 97 & 97 & 97 & 97 & 97 \\
\hline LSWB & $\begin{array}{l}\text { Pearson } \\
\text { Correlation }\end{array}$ &, $885^{* *}$ &, $869^{* *}$ &, $845^{* *}$ &, $838^{* *}$ & 1 &, $308^{* *}$ \\
\hline & Sig. (2-tailed) & ,000 & ,000 & ,000 & ,000 & & ,002 \\
\hline & $\mathrm{N}$ & 97 & 97 & 97 & 97 & 97 & 97 \\
\hline REDM & $\begin{array}{l}\text { Pearson } \\
\text { Correlation }\end{array}$ &, $263^{* *}$ &, $205^{*}$ & ,181 &, $392^{* *}$ &, $308^{* *}$ & 1 \\
\hline & Sig. (2-tailed) & ,009 & ,044 & ,076 & ,000 & ,002 & \\
\hline & $\mathrm{N}$ & 97 & 97 & 97 & 97 & 97 & 97 \\
\hline
\end{tabular}

**. Correlation is significant at the 0.01 level (2-tailed).

*. Correlation is significant at the 0.05 level (2-tailed).

Implikasi hasil penelitian. Ada beberapa implikasi dari hasil penelitian ini. Pertama, model pengukuran kesehatan spiritual, baik yang ideal (Ideal Spiritual Well-Being/ISWB) maupun pengalaman spiritual (Lived Spiritual Well-Being/LSWB) yang dikembangkan oleh Fisher pada tahun 2010 valid dan dapat diandalkan untuk mengukur konstruk ISWB dan $L S W B$. Kedua, model pengukuran orientasi keputusan etis (ethical orientation of decision making), baik yang ideal (IEDM) maupun yang relatif (REDM) yang dikembangkan oleh Forsyth pada tahun 1980 juga valid dan dapat diandalkan untuk mengukur konstruk IEDM dan REDM. Ketiga, dalam pengujian hipotesis 1 (Ha1) yaitu tentang keterkaitan ISWB dengan IEDM dan dimensi-dimensi ISWB (ICSWB, IPSWB, $I T S W B, I E S W B$ ) dengan IEDM semuanya menunjukkan adanya keterkaitan secara positif dan signifikan pada level 0.01. Hasil ini mendukung hasil penelitian yang telah dilakukan oleh Fernando dan Chowdhury (2010). Keempat, dalam pengujian hipotesis 2 (Ha2) yaitu tentang keterkaitan $L S W B$ dengan REDM dan dimensi-dimensi $L S W B$ (LCSWB, LPSWB, $L T S W B, L E S W B$ ) dengan $R E D M$ menunjukkan adanya keterkaitan secara positif dan signifikan pada level 0.01 antara $L S W B$ secara keseluruhan dengan $R E D M$, sedangkan 
hasil pengujian keterkaitan dimensi-dimensi $L S W B$ dengan REDM menunjukkan hasil yang bervariasi. Meskipun hasilnya bervariasi, namun seluruh dimensi $L S W B$ konsisten menunjukkan keterkaitan positif dengan REDM, sedangkan yang bervariasi hanyalah tingkat signifikansi keterkaitannya. Hasil ini juga mendukung hasil penelitian yang telah dilakukan oleh Fernando dan Chowdhury (2010).

Implikasi dari hasil penelitian di atas adalah bahwa upaya untuk mengembangkan pemahaman dan pengalaman kesehatan spiritual dalam semua bidang, apakah dalam dunia pendidikan, dunia bisnis, dunia politis, atau dalam kehidupan sehari-hari, di samping faktor-faktor lainnya, diyakini akan mampu untuk meningkatkan kualitas etikal suatu keputusan. Hasil penelitian ini semakin menguatkan hasil-hasil penelitian sebelumnya yang telah dilakukan oleh, antara lain: Fernando dan Chowdhury (2010); Hocking, Myers, dan Cairns (2009); Zohar dan Marshall (2005b); Amalia dan Yunizar (2007); Rochmah dan Prihatiningtias (2012), dan lain-lainnya. Dengan makin banyaknya hasil-hasil penelitian yang telah memberikan bukti empiris dimana tingkat kesehatan spiritual dalam berbagai aspek kehidupan sehari-hari, akan mampu mengurangi praktik-praktik keputusan yang tidak etis, maka sudah saatnya pendidikan, pelatihan dan pengembangan kesehatan spiritual diberikan sejak dini, khususnya dimasukkan dalam kurikulum pendidikan formal di sekolah-sekolah dan pendidikan tinggi, disamping pelatihan-pelatihan yang diberikan di lembaga pemerintahan dan bisnis.

\section{PENUTUP}

Simpulan. Simpulan dari hasil penelitian ini adalah: pertama, model pengukuran konstrak kesehatan spiritual yang dikembangkan oleh Fisher adalah valid dan dapat diandalkan; kedua, model pengukuran konstrak orientasi etikal keputusan Forsyth juga valid dan dapat diandalkan; ketiga, terdapat keterkaitan secara positif dan signifikan antara variabel kesehatan spiritual ideal, baik secara keseluruhan (ISWB) maupun masing-masing dimensi (ICSWB, IPSWB, ITSWB, IESWB) dengan orientasi etikal ideal pembuatan keputusan (IEDM); keempat, terdapat keterkaitan secara positif dan signifikan antara variabel pengalaman kesehatan spiritual secara keseluruhan (LSWB)) dengan orientasi relatif etikal pembuatan keputusan (REDM); kelima, meskipun hasil pengujian keterkaitan masingmasing dimensi pengalaman kesehatan spiritual: LCSWB, LPSWB, LTSWB, dan LESWB dengan orientasi etikal relatif pembuatan keputusan (REDM) menunjukkan signifikansi keterkaitan yang bervariasi, namun seluruh dimensi menunjukkan keterkaitan secara positif dengan konstruk REDM.

Penelitian ini memiliki kendala atau keterbatasan, antara lain: pertama, ruang lingkup sampel penelitian yang masih terbatas hanya di sekitar Jakarta saja; kedua, pengembalian kuesioner dari responden perusahaan publik masih sangat sedikit; ketiga, belum ada model pengukuran kesehatan spiritual dan orientasi etikal keputusan yang sudah bersifat baku.

Ada tiga saran yang dapat diberikan setelah melakukan penelitian ini. Pertama, bagi para peneliti selanjutnya, mengingat penelitian tentang kesehatan spiritual dan orientasi etikal pembuatan keputusan masih relatif baru maka disarankan untuk tetap melakukan pengujian-pengujian terhadap model-model pengukuran yang dikembangkan oleh penelitipeneliti lainnya. Kedua, sampel dan responden penelitian bisa diperluas ke berbagai institusi atau organisasi; Ketiga, bagi pengelola pendidikan, pejabat pemerintahan, pimpinan perusahaan, dan organisasi-organisasi lainnya, mungkin sudah saatnya untuk 
memasukkan kesehatan spiritual sebagai bagian dari mata kuliah, mata ajar, atau mata diklat etika atau budi pekerti, mengingat berdasarkan hasil-hasil penelitian, terdapat keterkaitan nyata secara positif antara kesehatan spiritual dengan orientasi etikal keputusan.

\section{DAFTAR RUJUKAN}

Agbim, K.C., F.A. Ayatse \& G.O. Oriarewo. (2013) Spirituality, ethical behaviour and ethical business: the impact of relatedness, Journal of Business Management \& Social Sciences Research, (JBM\&SSR) ISSN No: 2319-5614, 2(9) September.

Agoes, S. dan IC. Ardana. (2011) Etika bisnis dan profesi: tantangan membangun manusia utuh. Jakarta: Penerbit Salemba.

Ardana, IC., E.S. Dermawan, M. Susanti. (2016) "Spiritualitas Tempat Kerja (Workplace Spirituality) dan Motivasi Manajemen Laba (Earning Motivation Management)", Jurnal Akuntansi, XX (01), 86-103, Januari.

Amalia, F. dan Yunizar. (2007) "Perilaku dan spiritualitas di tempat kerja", Jurnal Busines \& Manajemen, 8, 13-23.

Aravamudhan, N.R. (2007) workplace spirituality, Suverna International Institute of Management Studies, India. http://www.indianmba.com, diakses 12 Juli 2012.

Chan, L. M., and J. Othman, (2011) "The conceptual model of Personal Moral Philosophy (PMP) and Ethical Decision Making (EDM)", Journal of Management Research, ISSN 1941-899X, 3 (2), E16.

Chappell, Stace (Editor) (2016) Management, Spirituality, and Religion (MSR) Ways and Means: A 2016 working paper to encourage quality research, August 1, stacie.chappell@wne.edu.

Covey, S.R. (2005) The 8th habit, alih bahasa Wandi S. Brata, Jakarta: PT Gramedia.

Dinger, T.J. (1997) The Relationship between Two Ethical Decision-Making Models and Conselor Trainee'Responses to an Ethical Discrimination Task and their Perceptions of Ethical Therapeutic Behavior, a Dissertation in Counselor Education, Texas Teach University.

Evans, A.M., D.H. Levitt, S. Henning. (2012) "The Application of Ethical DecisionMaking and Self-Awareness in the Counselor Education Classroom, Journal of Counselor Preparation and Supervision", 4 (2) October.

Fernando, M. dan R. Chowdhury. (2010) The relationship between spiritual well-being and ethical orientations in decision making: an empirical study with business executives in Australia; Research Online; Faculty of Business - University of Wollongong.

Fisher, J. (2010) Development and application of a spiritual well-being questionnaire called SHALOM, Religions 2010, 1, 105-121; doi:10.3390/rel1010105.

Forsyth, D. R.. (1980) “A taxonomy of ethical ideologies", Journal of Personality and Social Psychology, 39(1), 175-184.

Greeta, M., J. Pooja, Mishra PN. (2016) Ethical Behaviour in Organizations: A Literature Review, Published with open access at www.questjournals.org

Giacalone, R.A. and C.L. Jurkewicz. (2003) Toward a Science of Workplace Spirituality, The Handbook of Workplac Spirituality and Organizational Performance, M.E. Sharpe, Armonk, NY. 
Ghozali, Imam, (2009) Aplikasi Analisis Multivariate dengan Program SPSS, Semarang: Badan Penerbit Undip.

https://en.wikipedia.org/wiki/Accounting_scandals, Accounting scandals, diakses 30/01/2016.

http://www.who.int/, Definition of Health, World Health Organization, diakses $16 / 02 / 2016$.

http://wellness.ucr.edu/spiritual, Spiritual wellness, University of California, Riverside/UCR.

Johnsson, F. (2009) Personality measures under focus: The NEO-PI-R and the MBTI, Griffith University Undergraduate Student Psychology Journal, Volume 1.

Khavari, K, A. (2000) The art of happiness, alih bahasa Agung Prihantoro, Jakarta: PT Serambi Ilmu Semesta.

Koshuta, J.. (2015) What is Spiritual, Health-Definition \& Examples, http://studi.com/academy, diakses 16/02/2016.

Leonard, B., \& D. Carlson, (--), Introduction to Spirituality, Touro Institute, http://www.touroinstitute.com/, diakses 06/02/2016.

Lincoln, S.H., and Elizabeth K.H. (2011) "Ethical Decision Making: A Process Influenced by Moral Intensity", Journal of Healthcare, Science and the Humanities, 1 (1).

McGhee, P.K. (2015) The role of spirituality in ethical decision making and behaviour and the benefits to organisations: a critical realist analysis, a thesis submitted in fulfilment of the requirements for the degree of Doctor of Philosophy in Management, at The University of Auckland, 2015, ResearchSpace@Auckland, http://researchspace.auckland.ac.nz.

McGhee, P.K. dan P. Grant. (2008) "Spirituality and ethical behaviour in the workplace: wishful thinking or authentic reality", EJBO Electronic Journal of Business Ethics and Organization Studies, I.13,No.2 (2008), http://ejbo.jyu.fi/.

Morton, D., Byrne, C., Dahling, J., \& Chau, S. (2011) Spirituality, religion, and emotional labor in the workplace. Paper presented at the annual meeting of the Academy of Management, San Antonio.

Rochmah, N. dan Y.W. Prihatiningtias. (2012) "Pengaruh kecerdasan intelektual (IQ) dan kecerdasan spiritual (SQ) terhadap persepsi mahasiswa akuntansi mengenai keetisan praktek earnings management", Jurnal Ilmiah Mahasiswa FEB, 1 (2).

Selman, V., et al. (2005) Spiritual-intelligence/-quotient, College Teaching Methods \& Styles Journal - Third Quarter, 1 (3).

Simanjorang, D., dan F.Sipayung. (2012) "Pengaruh kecerdasan intelektual, kecerdasan emosional dan kecerdasan spiritual terhadap sikap etis mahasiswa manajemen Fakultas Ekonomi, Universitas Sumatra Utara", Jurnal Ekonom, 15 (2) April.

Schwartz, T., and C. McCarthy. (2007) Manage Your Energy, Not Your Time, Harvard Business Review, October. https://hbr.org/search.

Tunajek, S.K., (2012) Paths Connecting Mind, Body and Spirit, AANA NewsBulletin, September, http://www.aana.com

Wang, Yingxu \& G.Ruhe. (2007) The Cognitive Process of Decision Making, Int'| J ournal of Cognitive Informatics and Natural Intelligence, 1(2),73-85.

WHO. (2013) 'Spiritual health, the fourth dimension: a public health perspective', WHO South-East Asia Journal of Public Health, January-March, 2(1). 